\title{
Predictive Clinical Parameters for the Therapeutic Efficacy of Sitagliptin in Korean Type 2 Diabetes Mellitus (Diabetes Metab J 2011;35:159-65)
}

\author{
Jee-Young Oh \\ Department of Internal Medicine, Ewha Womans University School of Medicine, Seoul, Korea
}

Type 2 diabetes mellitus (T2DM) is a complex progressive metabolic derangement associated with comorbidities such as obesity, dyslipidemia, and hypertension. Although a wide range of pharmacotherapies is available for T2DM, determining management strategies for T2DM that balance effectiveness, safety, and tolerability remains complex and challenging.

The prevalence of T2DM has increased rapidly in Asia, including South Korea, over the past several decades [1]. The pathophysiologic mechanisms underlying T2DM in Asia are thought to be different from those in Western countries. In particular, pancreatic $\beta$-cell dysfunction may be important for the development of T2DM in certain Asian populations $[2,3]$.

Progressive $\beta$-cell failure, weight gain and hypoglycemia are the main side effects of sulfonylurea, one of the most commonly used antidiabetic agents. Long-term use of sulfonylurea can lead to the failure of monotherapy and ultimate dependence on insulin injections. Glucagon like peptide (GLP)-1 stimulates pancreatic $\beta$-cell differentiation and proliferation, and inhibits apoptosis [4]. Dipeptidyl peptide-4 (DPP-4) inhibitors enhance levels of active incretin hormones, gut-derived peptides that are released into the circulation after eating [5]. Sitagliptin is an oral, once-daily, potential, highly selective DPP-4 inhibitor. Numerous clinical studies of sitagliptin have been reported since the US Food and Drug Administration approved sitagliptin for monotherapy or combination therapy with metformin or thiazolidinedione in 2006 [5-9]. According to a system- ic review and meta-analysis, DPP- 4 inhibitors lowered HbA1C by $0.74 \%$ ( $95 \%$ confidence interval [CI], $0.62 \%$ to $0.85 \%$ ) compared with placebo [10].

Most studies indicate that sitagliptin treatment leads to significant improvements in $\beta$-cell function. Given the important role that $\beta$-cell dysfunction plays in the progression of hyperglycemia, especially in Asian patients, sitagliptin treatment may be of particular therapeutic relevance for T2DM in Asian contexts. However, clinical studies of sitagliptin therapies in Asian or Korean diabetic patients are rare. A 2009 study found that 18 week sitagliptin monotherapy was associated with significantly improved glycemic control (mean $\mathrm{HbAlc}$ reduction, $-1.0 \%$ ) and was well tolerated by T2DM patients from China, India, and Korea [11]. According to this study, the reduction of $\mathrm{HbA1C}$ relative to placebo was greater in Korean and Indian patients than in Chinese patients. The mean (95\% CI) reductions in $\mathrm{HbA1C}$ with sitagliptin treatment were $-1.4 \%$ $(-1.9 \%$ to $-0.8 \%)$ in Korean patients, $-1.4 \%(-1.7 \%$ to $-1.0 \%)$ in Indian patients, and $-0.7 \%(-0.9 \%$ to $-0.5 \%)$ in Chinese patients. Furthermore, Korean patients showed the greatest reductions of fasting glucose and 2-hour postprandial glucose levels. However, the reasons for these differences were not elucidated, although the authors suggested regional differences in environment, genetics, or adherence to study co-interventions such as diet and exercise.

Due to the current insufficiency of Asian or Korean data re-
Corresponding author: Jee-Young Oh

Department of Internal Medicine, Ewha Womans University Mokdong

Hospital, 911-1 Mok-dong, Yangcheon-gu, Seoul 158-710, Korea

E-mail: jyoh@ewha.ac.kr
This is an Open Access article distributed under the terms of the Creative Commons Attribution Non-Commercial License (http://creativecommons.org/licenses/by-nc/3.0/) which permits unrestricted non-commercial use, distribution, and reproduction in any medium, provided the original work is properly cited. 
garding sitagliptin efficacy in patients with T2DM, the study by Kim et al. [12] is particularly relevant. In that study, younger, thinner diabetic patients were observed to have better therapeutic results than older, heavier patients, suggesting that BMI and age should be considered before the selection of sitagliptin or other DPP-4 inhibitors for use in diabetic therapies. Treatment response was defined as $>10 \% \mathrm{HbAlc}$ reduction or $>20 \%$ fasting glucose reduction, and by this definition, the frequency of response in their sample was $81 \%$. As many previous clinical studies defined successful glucose-lowering effects according to the number of patients with $\mathrm{HbAlc}<7 \%$, additional studies are necessary to assess the therapeutic effects of sitagliptin and to identify clinical characteristics of patients that predict sitagliptin response.

\section{CONFLICTS OF INTEREST}

No potential conflict of interest relevant to this article was reported.

\section{REFERENCES}

1. Yoon KH, Lee JH, Kim JW, Cho JH, Choi YH, Ko SH, Zimmet P, Son HY. Epidemic obesity and type 2 diabetes in Asia. Lancet 2006;368:1681-8.

2. Matsumoto K, Miyake S, Yano M, Ueki Y, Yamaguchi Y, Akazawa S, Tominaga Y. Glucose tolerance, insulin secretion, and insulin sensitivity in nonobese and obese Japanese subjects. Diabetes Care 1997;20:1562-8.

3. Kim DJ, Lee MS, Kim KW, Lee MK. Insulin secretory dysfunction and insulin resistance in the pathogenesis of Korean type 2 diabetes mellitus. Metabolism 2001;50:590-3.

4. Holst JJ, Gromada J. Role of incretin hormones in the regulation of insulin secretion in diabetic and nondiabetic humans. Am J Physiol Endocrinol Metab 2004;287:E199-206.

5. Drucker DJ, Nauck MA. The incretin system: glucagon-like peptide-1 receptor agonists and dipeptidyl peptidase-4 inhibitors in type 2 diabetes. Lancet 2006;368:1696-705.

6. Raz I, Hanefeld M, Xu L, Caria C, Williams-Herman D, Khatami H; Sitagliptin Study 023 Group. Efficacy and safety of the dipeptidyl peptidase-4 inhibitor sitagliptin as monotherapy in patients with type 2 diabetes mellitus. Diabetologia 2006;49: 2564-71.

7. Aschner P, Kipnes MS, Lunceford JK, Sanchez M, Mickel C, Williams-Herman DE; Sitagliptin Study 021 Group. Effect of the dipeptidyl peptidase-4 inhibitor sitagliptin as monotherapy on glycemic control in patients with type 2 diabetes. Diabetes Care 2006;29:2632-7.

8. Charbonnel B, Karasik A, Liu J, Wu M, Meininger G; Sitagliptin Study 020 Group. Efficacy and safety of the dipeptidyl peptidase-4 inhibitor sitagliptin added to ongoing metformin therapy in patients with type 2 diabetes inadequately controlled with metformin alone. Diabetes Care 2006;29:2638-43.

9. Nauck MA, Meininger G, Sheng D, Terranella L, Stein PP; Sitagliptin Study 024 Group. Efficacy and safety of the dipeptidyl peptidase-4 inhibitor, sitagliptin, compared with the sulfonylurea, glipizide, in patients with type 2 diabetes inadequately controlled on metformin alone: a randomized, double-blind, non-inferiority trial. Diabetes Obes Metab 2007;9:194-205.

10. Amori RE, Lau J, Pittas AG. Efficacy and safety of incretin therapy in type 2 diabetes: systematic review and meta-analysis. JAMA 2007;298:194-206.

11. Mohan V, Yang W, Son HY, Xu L, Noble L, Langdon RB, Amatruda JM, Stein PP, Kaufman KD. Efficacy and safety of sitagliptin in the treatment of patients with type 2 diabetes in China, India, and Korea. Diabetes Res Clin Pract 2009;83:106-16.

12. Kim SA, Shim WH, Lee EH, Lee YM, Beom SH, Kim ES, Yoo JS, Nam JS, Cho MH, Park JS, Ahn CW, Kim KR. Predictive clinical parameters for the therapeutic efficacy of sitagliptin in Korean type 2 diabetes mellitus. Diabetes Metab J 2011;35:15965. 